九州大学学術情報リポジトリ

Kyushu University Institutional Repository

\title{
A revision of the genus Euops Schoenherr (Coleoptera : Attelabidae) from Japan, Korea and Taiwan
}

Sawada, Yoshihisa

Entomological Laboratory, Faculty of Agriculture, Kyushu University

Morimoto, Katsura

Entomological Laboratory, Faculty of Agriculture, Kyushu University

https://doi.org/10.5109/23823

出版情報：九州大学大学院農学研究院紀要. 30 (2/3)，pp. 175-195，1985-12. Kyushu University バージョン：

権利関係 : 


\title{
A revision of the genus Euops Schoenherr (Coleoptera : Attelabidae) from Japan, Korea and Taiwan*
}

\author{
Yoshihisa Sawada and Katsura Morimoto \\ Entomological Laboratory, Faculty of Agriculture, \\ Kyushu University, Fukuoka 812, Japan \\ (Received 0 ctober 7, 1985)
}

\begin{abstract}
This paper deals with the classification of the Japanese, Korean and Taiwanese species of the genus Euops Schoenherr. Eleven species and one subspecies are recognized, two new species, konoi sp. nov. and clarus sp. nov. are described, two previously recognized species are placed in synonymy, phaedonius Sharp with punctatostriatus Motschulsky and matsumurana Kôno with indigenus Voss, and championi Voss is newly recorded from Taiwan. The taxon koreanus, which has been established as a forma of E. lespedezae, is regarded as a subspecies of the latter. The species are characterized by the morphological features of the male external genitalia, size of the eyes, sculpture of the pronotum and shapes of the tibiae and the male venter. Redescriptions, illustrations of the important characters, and key to species are given.
\end{abstract}

Euops Schoenherr is a well-marked genus composing the tribe Euopini in the subfamily Attelabinae, and includes more than 100 species from the Oriental and the Malagasy Regions, and the East-African, Austrotasmanian, Melanesian and Manchulian Subregions. Voss $(1924,25)$ published monograph of the genus of the world, and Kôno (1927) revised the Japanese, Korean and Taiwanese species and recognized 10 species from there. Hirano (1954) reviewed the Japanese species and classified them into 5 species, but Chûjô and Morimoto (1959) recognized 6 species from Japan and gave a key to species.

In this paper, we intend to revise the species of the genus Euops from Japan, Korea and Taiwan, based on the detailed re-evaluation of the diagnostic characters, together with description of two new species, notes on two new synonymies and record of a species new to the fauna of Taiwan.

It is with pleasure that we express our gratitude to Prof. Y. Hirashima of Kyushu University for his guidance and encouragement. We are grateful to Dr. K. Baba, Messrs. T. Kishii, K. Yamagishi, K. Ôhara and H. Takemoto for their kindness in offering valuable materials, and to Mr. S. Naomi for his valuable advice.

* Contribution from the Entomological Laboratory, Faculty of Agriculture, Kyushu University, Fukuoka (Ser. 3, No. 199). 


\section{Genus Euops Schoenherr}

Euops Schoenherr, 1839, Gen. Sp. Curc., V, 1: 318; Jekel 1860, Ins. Saunders., II: 219; Lacordaire, 1863, Gen. Col., VI: 550; Sharp, 1889, Trans. Ent. Soc. London, 1889: 54; Schilsky, 1903, Käf. Eur., XL: B; Voss, 1924, Deut. Ent. Zeit., 1924: 13-65 (monograph); Voss, 1925, Stett. Ent. Zeit., 85: 302 (monograph); Kôno, 1927, Ins. Mats., II: 39-44 (Japanese species); Dalla-Torre et Voss, 1930. Col. Cat., 110: 30-37; Ter-Minassian, 1950, Fauna SSSR., 27 (2): 178; Voss, 1953, Col. Cat. Suppl., 144 et 110: 13-16; Hirano, 1954, Kontyû, 21: 1-9 (Japanese species) :Voss, 1958, Decheniana Beih., 5: 14 (Fukien species) ; Chûjô et Morimoto, 1959, Kontyû, 27: 146 (Key to Japanese species) ; Morimoto, 1962b, J. Fac. Agr., Kyushu Univ., 12: 28.

Type-species : Euops australasiae Fahraeus (1839, nec Hope) (=Attelabus falcatus Guérin, 1838), by original designation.

This genus is easily distinguishable from the other genera of the Attelabinae by the large and almost contiguous eyes, the brush-like pubescence on the female venter, and absence of the labial palpi. Classification on the species level is, however, often confusing, because of the insufficient evaluation of the diagnostic characters.

The important characters we have assigned are as follows:

Sculpture of pronotun. The genus Euops was divided into 4 subgenera by the difference of the sculpture on pronotum by Voss (1924). The sculpture of the pronotum in the species of Japan, Korea and Taiwan treated in this paper can be classified into 5 states:

1: wrinkled punctate.

2: sparsely punctate.

3: vortically punctate.

4: tuberculate.

5: uniformly and strongly punctate.

Spearation of the first two states is often delicate in certain species due to intraspecific variation.

Size of eyes. The eyes are broadly or narrowly separated by the linear forehead (Fig. 1), contacted to each other at a point (Fig. 2), or completely contiguous for a considerable length (Figs. 3, 4), according to the relative size of the eyes to the head. The eyes are often discoloured in specimens leaving blackish peripheries and are visibly smaller at a glance.

Elytra and its relating structures. The elytra are weakly dilated posteriorly in the species with relatively large abdomen and elongate elytra, while in the species with shorter abdomen, the elytra are shorter and tapered posteriorly. The 1st stria of the elytra approaches to the sutural ridge in the middle of elytra, then parallel on the posterior half in most species, or the 1st stria is gradually converging posteriorly to the suture in some species, as already stated by Voss for chinensis. The 9th stria confluents with the 10th above the 1st ventrite in most species (Fig. 39), but it is free in entire length in some species (Fig. 37). The venter is often costate along lateral margins of elytra (Figs. 17, 18).

Tibiae. The tibiae are sexually dimorphic in all species. In the male, 

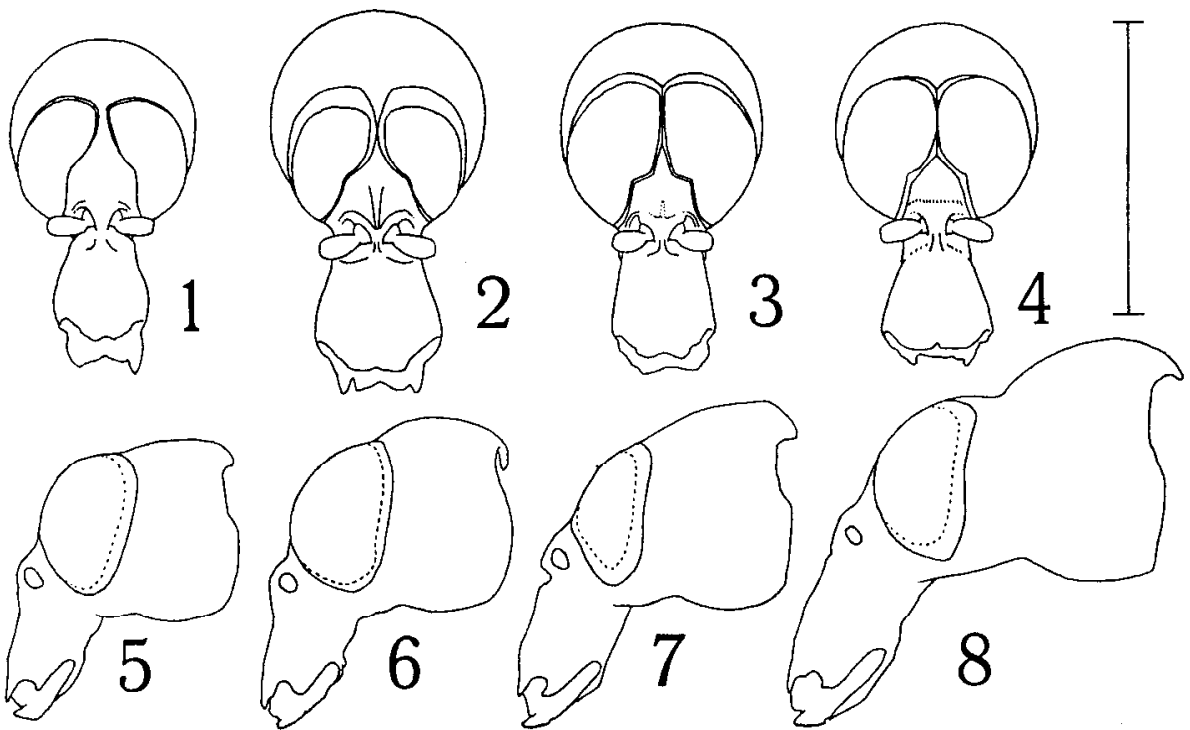

Figs. 1-4. Male heads (in frontal view) of...1, Euops politus; 2, E. punctatostriatus; 3, E. konoi sp. nov.; 4, E. clarus sp. nov. Scale: $1 \mathrm{~mm}$.

Figs. 5-8. Male heads (in left lateral view) of...5, E. konoi sp. nov.; 6, E. clams sp. nov.; 7, E. punctatostriatus; 8, E. splendidus. Scale: $1 \mathrm{~mm}$.

apical part of the tibia is more strongly curved and the uncus is directed more downward than in the female. The male fore tibiae of certain species are longer and evenly curved (Fig. 39), or the male middle tibiae of some other species are dilated apically and laminate (Figs. 10, 11) or project dorso-apically (Fig. 12). The laminate projection of the male middle tibia obstructs upward movement of the female hind femur by grasping the anterolateral part of the female venter in the male middle tibiae, when the male mounts on the female. The relative length of the male fore leg to the body length correlates with the function of the male fore leg in copulation or mounting. The relatively longer and arched tibiae are hooked on the anterior margin of the female elytra with their unci as observed in $\boldsymbol{E}$. lespedezae, $\boldsymbol{E}$. punctatostriatus, or the relatively shorter and straight ones are put to the lateral surfaces of the female body as in E. konoi when mating. In the female, fore and middle tibiae of certain species are angularly dilated at the middle (Fig. 13), or fore, fore and middle, or all tibiae of some species are mucronate as in the other genera of Attelabidae (Fig. 14).

Venter. The venter is also sexually dimorphic in all species. The male venter is specific in their shapes and sculptures (Figs. 19-23). While in the female, the interspecific differences are not remarkable and the basal 3 ven. trites are furnished each with double rows and the 4th with a single row of erect pubescence. The rolled-up cradle is carefully brushed by the female with the ventral pubescence. Then the cradle is severed from the plant, falls 


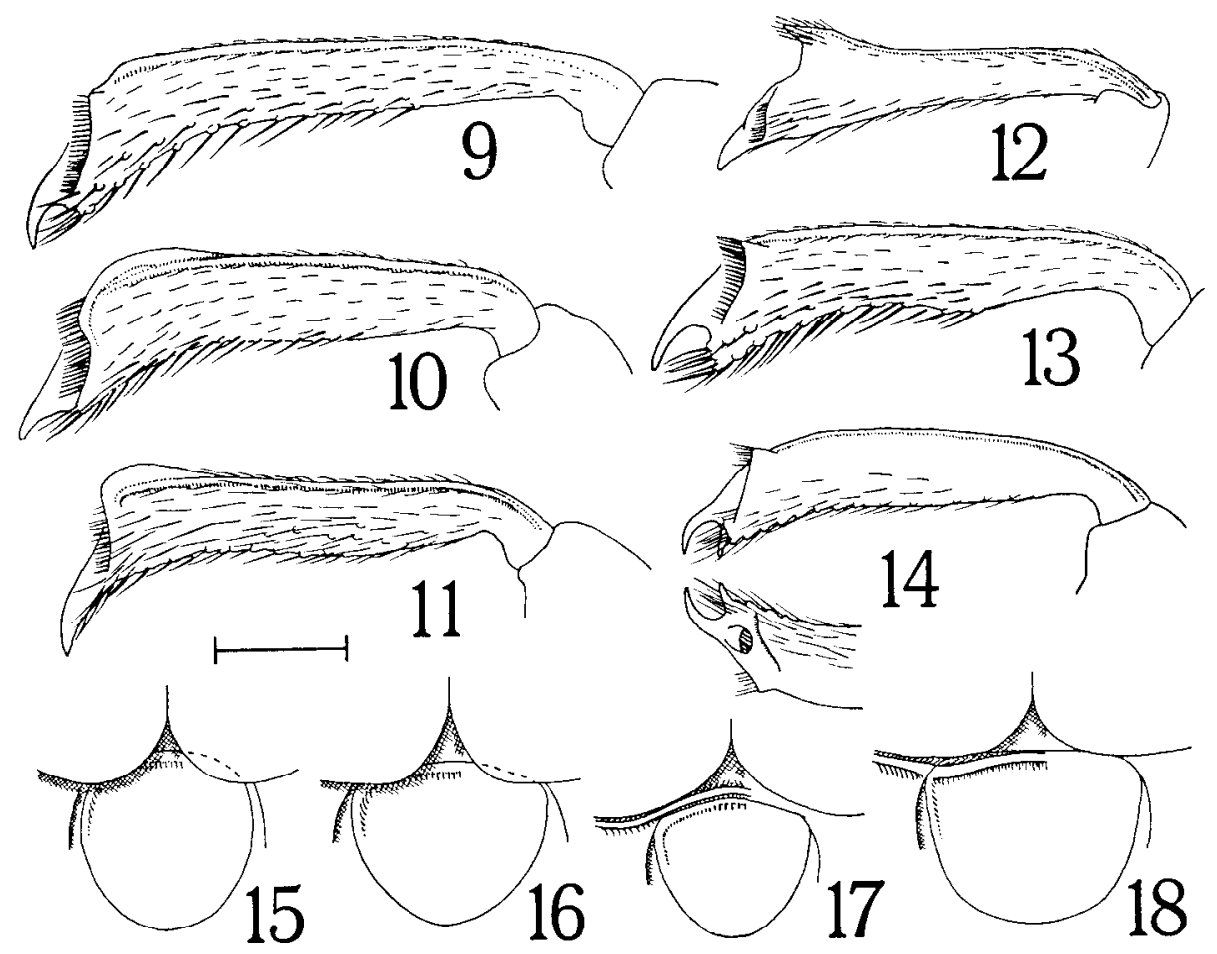

Figs. 9-14. Right middle tibiae of...9, Euops splendidus $\precsim ; 10, E$. Cespedezae

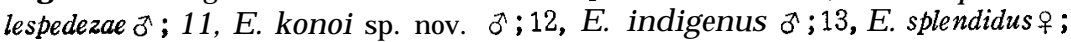
14, E. indigenus 우. Scale : $0.25 \mathrm{~mm}$.

Figs. 15-18. Pygidia, with posterior ends of elytra and venters of...15, $E$. politus ð̋; 16, E. politus 우; 17, E. punctatostriatus ð; 18, E. pustulosus ð. Scale : $0.5 \mathrm{~mm}$.

to the ground, and gets moldy soon with favorable fungi.

Male genitalia. The male genitalia offer good characters to recognize the species (Figs. 24-35), especially the endophallic structures are stable within species and drastically different among species as pointed out on North American Attelabidae by Hamilton (1979).

Key to species of the genus Euops from Japan, Korea and Taiwan

1 : Elytra tuberculate, irregularly punctato-striate; head elongate, constricted behind eyes; in male, fore tibiae elongate and arched; black with brown shimmer in general ....................... Euops (Kobusynaptops) pustulosus Sharp

- : Elytra not tuberculate, regularly punctato-striate . ............................. 2

2 : Pronotum uniformly sculptured, without transverse impression ; punctures of pronotum strong and dimple-like; black, underside with green lustre in general E. (Euops) championi Voss 

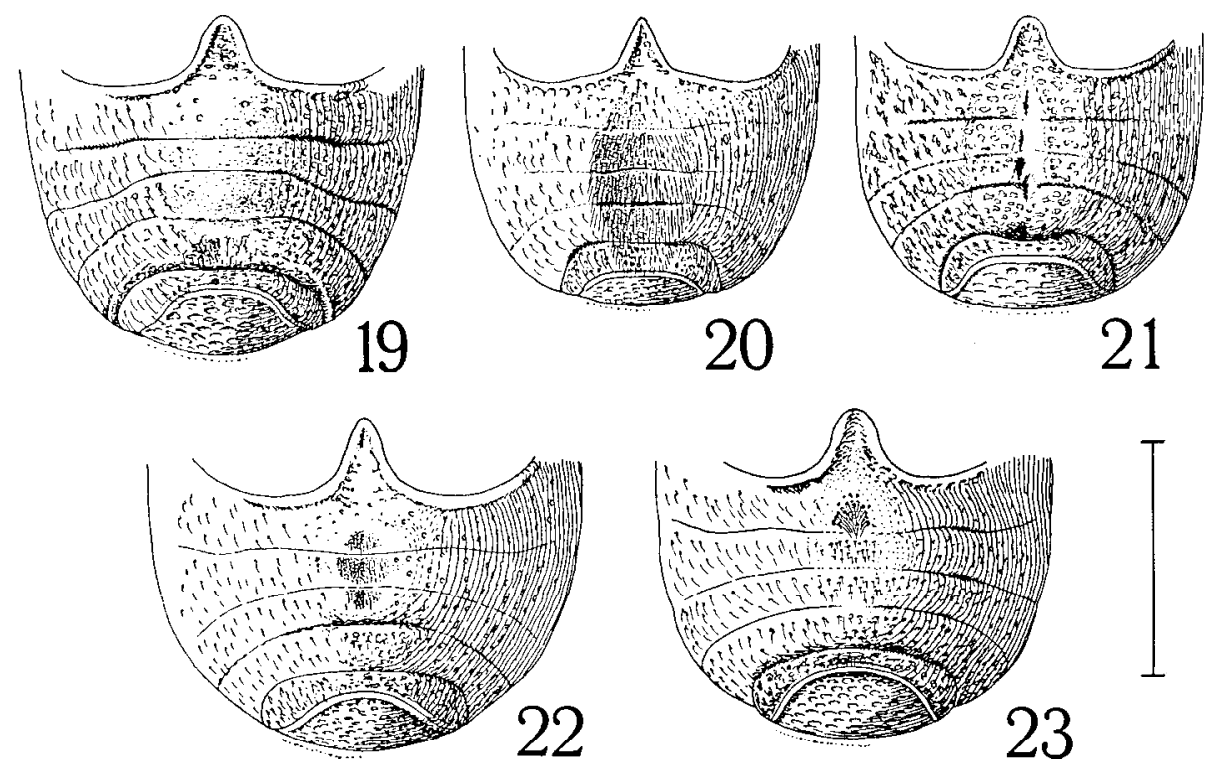

Figs. 19-23. Male venters (in ventral view) of...19, Euops championi; 20, E. indigenus; 21, E. clarus sp. nov.; 22, E. chinensis; 23, E. striatus. Scale :1 mm.

- : Pronotum unequally sculptured, partially wrinkled punctate, or with indefinite transverse impressions at middle or both sides of middle (subg. Synaptops)

3 : Pronotum vortically punctate; head elongate, constricted behind eyes; in male, fore tibiae elongate and arched

- : Pronotum not vortically punctate ; head not constricted; male fore tibiae almost as long as those in female ......................................... 8

4 : Eyes contiguous; punctures of pronotum very strong, arranged in vortical wrinkles; reddish black with brown shimmer in general

E. striatus Voss

Eyes separated, at most contact to each other at a point 5

5 : Pronotum not humped; pronotum with fine punctures, not wrinkly; pronoturn bluish or yellowish green with two dark stripes, elytra blue or purple in general ............................................................. chinensis Voss

- : Pronotum humped at middle and sides; pronotum partially wrinkled $\cdots . . . . .66$

6 : In male, first 4 ventrites conjointly with a hairy mesial hollow, middle tibia laminated; in female, frons grooved longitudinally $\ldots \ldots \ldots \ldots \ldots \ldots \ldots \ldots$.

- : In male, first 4 ventrites each with a minute hair tuft in the middle, middle tibiae scarcely laminated; in female, frons weakly impressed; pronotum green or yellow with two dark stripes, elytra blue or greenish blue in general ......................................................... splendidus Voss.

7 : Ventral plate of penis almost as broad as apex of tegmen; dark viola. ceous, purple or deep blue in general

E. lespedzae lespedezae Sharp 

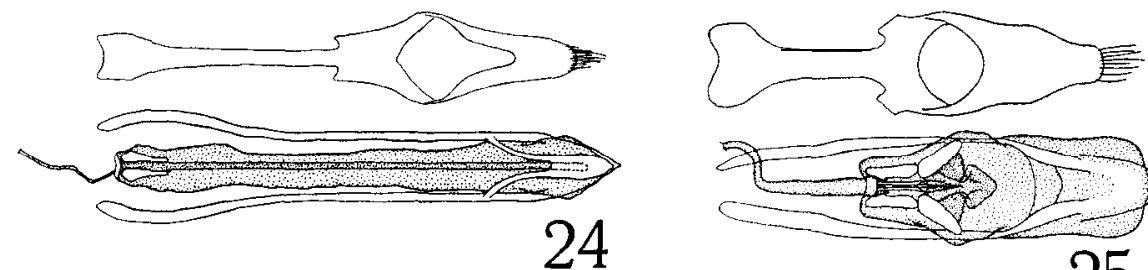

24
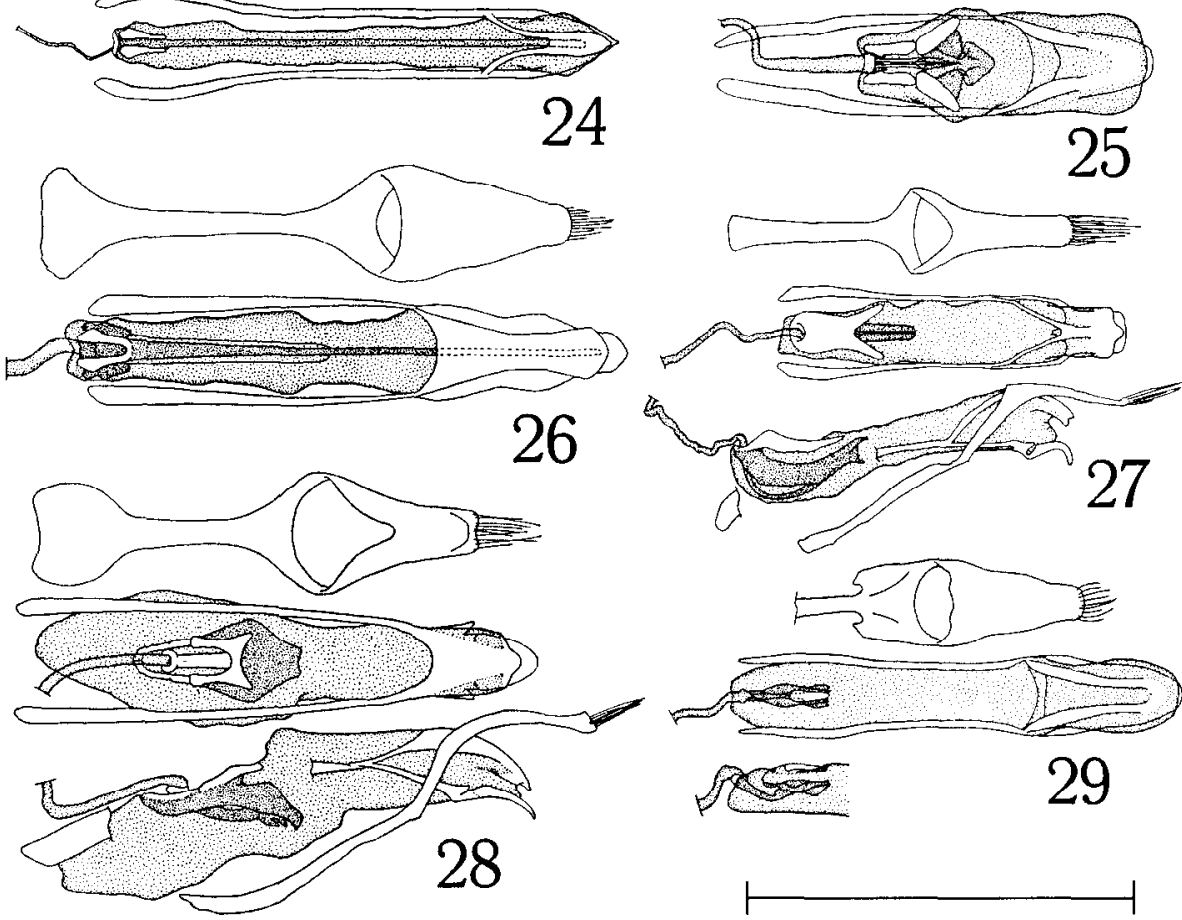

Figs. 24-29. Male genitalia of...24, Euops punctatostriatus; 25, E. championi; 26, E. indigenus; 27, E. politus; 28, E. Ronoi sp. nov.; 29, E. clarus sp. nov. Scale : $1 \mathrm{~mm}$.

- : Ventral plate much broader than apex of tegmen; dark violaceous or dull green, elytra greenish blue in general

E. lespedezae koreanus Voss, status nov.

8 : The 9th stria of elytra contact to 10 th above the 2 nd or 3 rd ventrite; in

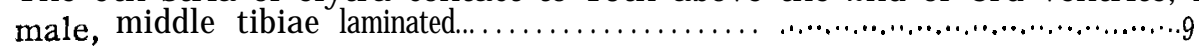

- : The 9th stria of elytra confluent with 10th above the 1st ventrite $\cdots . . . . .11$

9 : Eyes separated; pronotum finely and sparsely punctate, or strongly punctate and wrinkly; bluish green, yellowish green or brazen in general

E. politus (Roelofs)

- : Eyes contiguous

10: Elytra tapered posteriorly; pronotum transversely wrinkled ; in female, all tibiae mucronate; pronotum yellowish green or light orange, elytra green in general

E. clarus sp. nov.

- : Elytra almost parallel-sided except humeri; pronotum with sparse punctures, partially or wholly wrinkled at median impression; in female, tibiae 


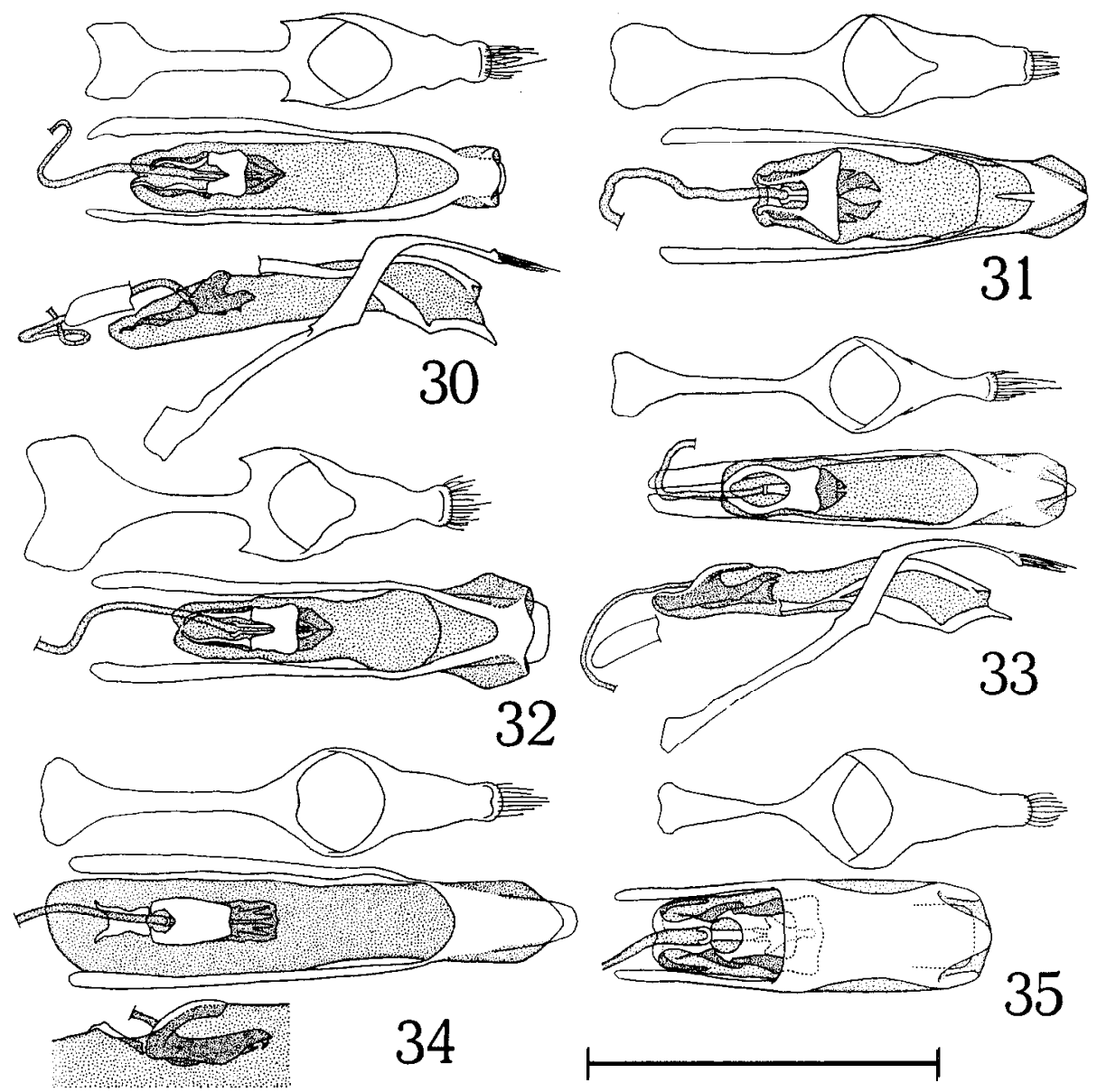

Figs. 30-35. Male genitalia of...30, Euops lespedezae lespedezae; 31, E. pustulosus; 32, E. lespedezae koreanus status nov.; 33, E. splendidus; 34, E. chinensis; 35, E. striatus. Scale: $1 \mathrm{~mm}$.

not mucronate; dull green or deep blue in general

E. konoi sp. nov.

11: Eyes contiguous; in male, middle tibiae laminated and projected dorso-apically; in female, middle tibiae mucronate; dull green or deep blue in general.......................................................... indigenus Voss.

- : Eyes separated, or at most contact at one point; in male, middle tibiae not laminated; in female, fore and middle tibiae mucronate; dull green or deep blue in general .......................... E. punctatostriatus (Motschulsky) .

Subgenus Euops s. str.

Jekel, 1860, Ins. Saunders., II: 221; Voss, 1924, Deut. Ent. Zeit., 1924: 39; Voss, 1925, Stett. Ent. Zeit., 85: 92. 


\section{Euops championi Voss}

(Figs. 19, 25, 40)

Euops championi Voss, 1929, Stett. Ent. Zeit., 90: 217-218, (India: Kumaon Ranikhet; Suini Gad Garhwal 4000ft.) ; Voss, 1942, Mitt. Münch. Ent. Ges., 32: 100, (Fukien: Kuatun L., 117.405" E. L., 2,300 m) ; Marshall, 1948, Novit. Zool., 42: 412, (Burma : Kambaiti) ; 27.40” N. Voss, 1958, Decheniana, Beih., 5: 14-15.

Matt, black ; head, femora, antero-lateral areas of prothorax and underside of body with green lustre. Eyes contiguous. Pronotum almost straightly narrowed anteriorly; punctures strong and dimple-like, interstices finely punctate.

Elytra almost parallel-sided in basal half except humeri; striae strongly punctate; intervals each with a row of large weak punctures, outer edges of intervals elevated; the 1st stria gradually approaching to elytral suture from base to apex; the 9th stria joining with 10th above the posterior end of 1 st ventrite. Venter costate along margins of elytra.

In male, the 1st to 4 th ventrites conjointly depressed, the depressed area hairless; genitalia with internal sac short, endophallic sclerites complex.

Specimens examined : Paleng, Taoyuan Hs., Taiwan, $10^{\star}, 21-23$. v. 1980, H. Makihara leg.; Mt. Lalashan 1300-1500 m, Taoyuan Hs., Taiwan, 2 ․, 17. iv. 1981, K. Ôhara \& H. Takemoto leg.

Distribution : India, Burma, China, Taiwan (new record).

\section{Subgenus Synaptops Jekel}

Jekel. 1860, Ins. Saunders., II: 221; Voss, 1924, Deut. Ent. Zeit., 1924: 39; Voss, 1925, Stett. Ent. Zeit., 85: 293; Kôno, 1927, Ins. Mats., II: 39; Ter-Minassian, 1950, Fauua SSSR., 27 (2) : 179.

Type-species : Euops Nietneri Jekel (1860) (=Rhynchites suffundens Walk., 1859). by original designation.

\section{Euops punctatostriatus (Motschulsky)}

(Figs. 2, 7, 17, 24)

Atellabus (sic) punctato-striutus Motschulsky, 1860, Etud. Ent., IX : 22 .

? Euops punctato-striatus: Sharp, 1889, Trans. Ent. Soc. London, 1889: 56.

Euops punctatostriata: Voss, 1924, Deut. Ent. Zeit., 1924: 43, 55; Voss, 1925, Stett. Ent. Zeit., 85: 297; Ter-Minassian, 1950, Fauna SSSR., 27 (2): 179,180; Kôno, 1950, Icon. Ins. Jap., Ed. sec.,: 1284; Hirano, 1954, Kontyû, 21: 4-6; Chûjô et Morimoto, 1959, Kontyû, 27: 146-147; Nakane, 1963, Icon. Ins. Jap. Col. nat. ed., Vol. 2 (Col.) : 335, pl. 178; Matoba, 1975, Nankiseibutsu, 17: 19, 20; Morimoto, 1984, Coleopt. Jap. Col., Vol. IV: 260, pl. 51.

Euops punctato-striata: Kôno, 1927, Ins. Mats., II: 39, 42-43; Yokoyama, 1931, Zoku Nihon no Kotyû, : 61, pl. 8 .

Euops phaedonius Sharp, 1889, Trans. Ent. Soc. London, 1889: 56; Voss, 1924, Deut. Ent. Zeit., 1924: 55. Syn. nov.

Euops phaedonia: Voss, 1924, Deut. Ent. Zeit., 1924: 43; Voss, 1924, Stett. Ent. Zeit., 85: 297. Syn. nov. 
Euops puncticollis Schilsky, 1906, (nec Boheman, 1859), Käf. Eur., XLII: 92.

Euops schilskyi Voss, 1922, Deut. Ent. Zeit., 1922: 174, (new name for puncticollis Schilsky). Euops aceri Kôno, 1926, Dobutsugakuzasshi, 38: 223, 224.

Euops punctato-striata f. aceri: Kôno, 1927, Ins. Mats., II: 40, 43.

Euops punctato-striata f. awana Kôno, 1927, Ins. Mats., II: 39, 43.

Eyes contact with each other at a point, often shortly contiguous in male, or slightly separated in female. Scutellum almost oblong, often constricted at middle. Elytra obviously tapered posteriorly; 9th stria confluent with 10th above 1st ventrite. Venter strongly costate along margins of elytra, costae continued to the posterior edge of 6 th tergite.

In male, fore tibiae scarcely longer than those in female; middle tibiae not laminate; 1 st to 4 th ventrites narrowly flattend medianly, not haired ; genitalia with long flagellum.

In female, fore and middle tibiae mucronate.

Specimens examined: 180 exs from Hokkaido, Aomori, Niigata, Tochigi, Gunma, Yamanashi, Miyagi, Nagano, Gifu, Toyama, Ishikawa, Fukui, Tokushima, Fukuoka, Oita and Kumamoto Prefs.

Distribution : Japan (Hokkaido, Rishiri Is., Honshu, Shikoku, Kyushu).

Note. Motschulsky (1860) briefly described this species as punctato-striatus under the genus Attelabus. Sharp (1889) described Euops phaedonius, and pointed out the possibility that Motschulsky's species also belongs to the genus Euops. Voss (1924) examined the type specimen of punctatostriatus and confirmed that this species is a member of the genus Euops. Voss (1924) distinguished punctatostriatus from phaedonius by the coloration alone and pointed out the possibility of their identity. The type of phaedonius in the British Museum (Natural History) is nothing but a greenish colour form of punctatostriatus.

\section{Euops indigenus Voss}

(Figs. 12, 14, 20, 26, 41)

Euops indigena Voss, 1924, Deut. Ent. Zeit., 1924: 278-279; Voss, 1925, Stett. Ent. Zeit., 85: 297; Kôno, 1927, Ins. Mats., II: 39-40, 43.

Euops matsumurana Kôno, 1927, Ins. Mats., II: 39, 42. Syn. nov.

Black, often reddish, with deep blue of green lustre.

Head sparsely punctate, constricted along the posterior margin of eyes in lateral aspect. Eyes large, contiguous for considerable length, conjointly convex and swollen from the outline of head. Rostrum longer than broad, shiny, with sparse minute punctures. Antennae with stout scape, funicle with 1st segment as long as scape, 2nd to 4th segments each longer than broad, 5th and 6th longer than or as long as broad, 7th as long as broad; club robust, two basal segments each almost as long as broad, or obviously longer than broad in small individuals, 3rd slightly shorter than 2nd, 4th cone-shaped.

Prothorax almost as long as broad, broadest at base, sides roundly narrowing anteriorly; subbasal constriction weak, anterior margin weakly or moder- 
ately emarginate ; transverse median impressions weak ; punctures minute, transversely or obliquely confluent and forming long weak wrinkles before the impression excepting the median area.

Scutellum oblong, weakly constricted at middle.

Elytra about 1.3 times as long as broad at humeri, roundly and moderately narrowed posteriorly in larger individuals, or slightly and almost straightly narrowed in smaller ones; punctures of striae strong or moderate, not weakened apically; intervals broader than striae, outer edges often weakly elevated, each interval with one or two irregular rows of minute punctures; 9 th stria joining with 10 th above 1 st ventrite.

Legs stout. Femora robust. Fore tibiae in male straight, almost as long as those in female, in female weakly expanded inward at middle. In male, middle tibiae with well developed and laminate dorso-apical projections, projections pointed apically, excavated on the posterior surface. In female, middle tibiae furnished each with a mucro.

Venter weakly costate on two posterior ventrites along margins of elytra. In male, venter broadly and shallowly impressed throughout the 1st to 4th ventrites, the impression with fine erect pubescence, which is longer on the peripheral region than the middle.

Male genitalia with long flagellum.

Length : 2.0-3.3 mm.

Specimens examined: 24 exs from Taipei, Taoyuan, Nantou, Hualien, Chiai and Pingtung Hss.

Distribution : Taiwan.

Note. This species is charcteristic in having the pointed projections of the middle tibiae and structures of the genitalia and venters in the male. These features are stable. On the other hand, this species is variable in many characters. First of all, it varies in the body size together with a series of correlated characters. Generally speaking, smaller the size, the body shape more elongate and flattened, punctures on the pronotum and the elytra weaker, the eyes smaller and less convex, the rostrum shorter, the funiculer segments of antennae shorter, and the club slenderer. Secondly, it is variable in the coloration of body, and two varieties are recognized, dark blue and green, and this variation does not correlate with morphological characters mentioned above. Judging from this observation, matsumurana, described by Kôno (1927) based on only one female, must be a larger green-coloured individual of indigenus, and newly synomymized with the latter in this paper.

\section{Euops politus (Roelofs)}

(Figs. 1, 15, 16, 27)

Attelabus politus Roelofs, 1874, Ann. Soc. Ent. Berg., 17: 140.

Euops politus: Sharp, 1889, Trans. Ent. Soc. London, 1889: 56; Schilsky, 1906, Käf. Eur., XLII : 93.

Euops polita: Voss, 1924, Deut. Ent. Zeit., 1924: 44. 57; Voss, 1925. Stett. Ent. Zeit., 85: 298; Kôno, 1927, Ins. Mats., II: 40, 44; Hirano, 1954, Kontyh, 21: 3-4; Chûjô et et Morimoto, 
1959, Kontyh, 27: 146-147; Matoba, 1975, Nankiseibutsu, 17: 19,20; Morimoto,1984, Coleopt. Jap. Col., Vol. IV: 259, p1. 51.

Eyes narrowly separated. Scutellum constricted at middle. Elytra almost parallel-sided except humeri, or slightly dilated posteriorly; 9th stria extends at least beyond the posterior margin of 1 st ventrite, and being in contact with 10 th above 3 rd ventrite in general, or sometimes above the 2 nd. Venter not costate along margins of elytra.

In male, fore tibiae scarcely longer than those in female; middle tibiae with distinct laminate projection; 1 st to 4 th ventrites broadly flattend medianly, the 5th also flattend in its anterior region; genitalia with endophallic sclerites complex and narrow, cap-piece caudate.

Specimens examined : 58 exs from Yamanashi, Nagano, Ishikawa, Kyoto, Hyogo, Hiroshima, Tottori, Ehime, Kochi, Fukuoka, Nagasaki and Oita Prefs.

Distribution : Japan (Honshu, Shikoku, Kyushu).

Note. This species is variable in sculpture of the prothorax, coloration and size among local populations; 2.3-3.1 $\mathrm{mm}$ in size; shiny bluish green to dim brass in colour; and the pronotum is finely punctate to wholly wrinkled.

Morimoto examined the type specimen in the British Museum (Natural History) and verified that this species has been rightly identified by entomologists.

\section{Euops konoi sp. nov.}

(Figs. 3, 5, 11, 28, 36, 37)

Euops phaedonia: Kôno, 1927, (nec. Sharp), Ins. Mats., II: 40, 43; Kôno, 1950, Icon. Ins. Jap., Ed. sec.,: 1284; Ter-Minassian, 1950, Fauna SSSR., 27 (2) : 179-180; Chûjô et Morimoto, 1959, Kontyû, 27: 146-147; Matoba, 1975, Nankiseibutsu, 17: 19, 20; Morimoto, 1984, Coleopt. Jap. Col. Vol. IV,: 259, pl. 51.

Male. Metallic green, shiny, legs and antennae black or dark brown with metallic lustre.

Head not constricted at base, separately with moderate punctures except for strigulated neck region. Rostrum 1.5 times as long as breadth at base, straightly dilated toward apex, closely punctate, apical half of dorsum sparsely punctate. Eyes large, contiguous for considerable length. Antennae standard to this genus; funicle with 1 st segment as long as scape, 2.5 times as long as broad, 2nd shorter than 1st, 3rd shorter than 2nd, 4th as long as 3rd, 5th shorter than 4th, 6th a little shorter than 5th, 7th as long as 6th, slightly longer than broad; club robust, 2nd segment as long as or slightly shorter than 1st, as long as broad, 3rd shorter than 2nd, three basal seqments almost of the same breadth, 2nd shorter than two apical segments taken together, 4th cone-shaped.

Prothorax as long as broad, broadest at base, constricted near base, then roundly narrowed anteriorly. Dorsum with a transverse or oblique impression at middle, with sparse punctures, which are wrinkly confluent at the impression. 


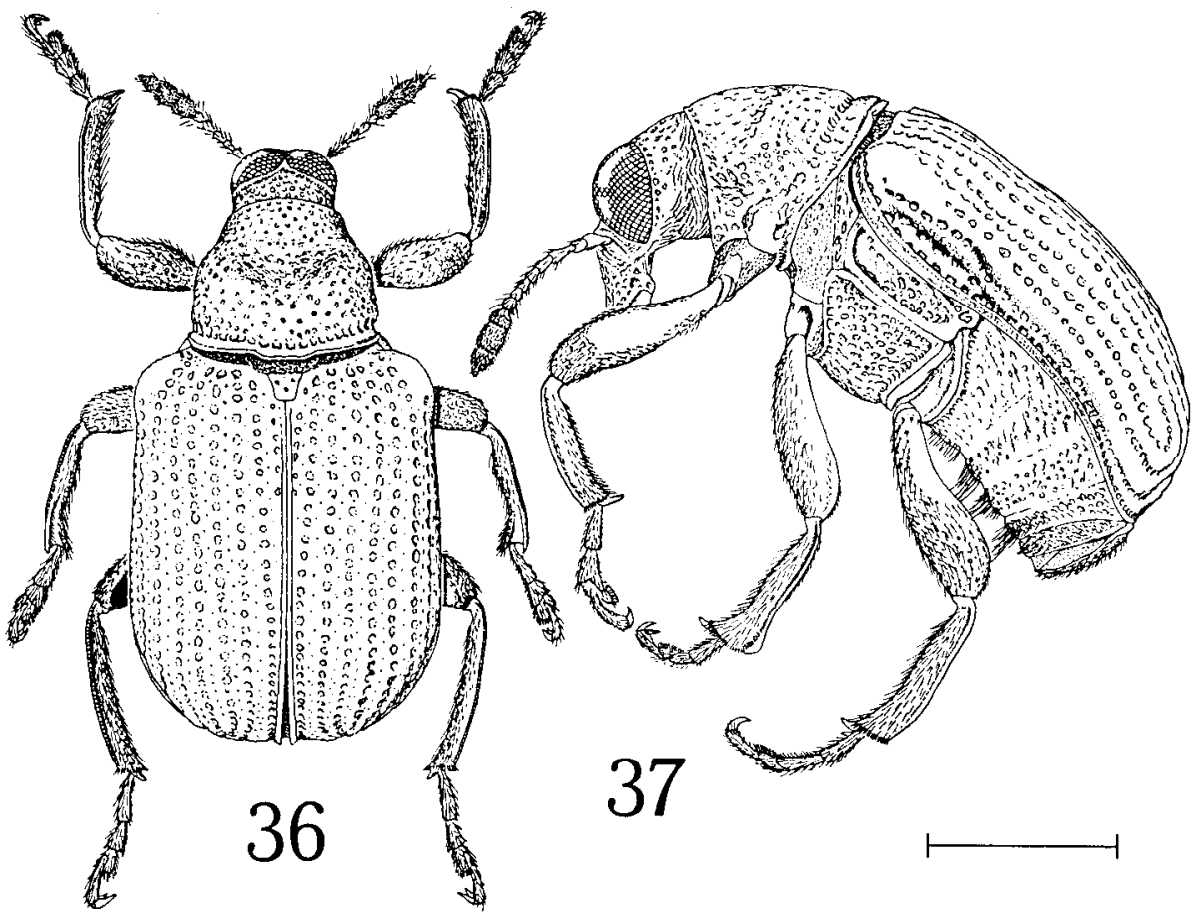

Figs. 36, 31. Euops konoi sp. nov. ð. Scale: $1 \mathrm{~m} \mathrm{~m}$.

Scutellum slightly longer than broad, trapezoid, oblong or sometimes constricted at middle.

Elytra 1.2-1.4 times as long as broad, slightly dilated posteriorly or at least parallel-sided except humeri ; striae narrower than intervals, punctures of stria indefinitely outlined, with peripheries overlap with adjacent punctures, so that striae slightly lower than intervals; intervals smooth, each with a row of minute punctures; 1st stria gradually approaching to the sutural ridge from base to declivity; 9 th and 10th striae not confluent throughout, but closely adjacent near apical $1 / 4$ of elytron.

Mesepisterna and mesepimera finely coriarious, sparsely punctate. Mesosternum closely and strongly punctate. Metepisterna closely punctate on the posterior half, and sparsely punctate and finely coriarious on the anterior half. Metepimera punctate. Metasternum transversely wrinkled and sparsely punctate in middle, strongly punctate on the lateral surface, punctures sometimes oval.

Legs stout. Femora clavate; hind femora slightly thicker than the others, sparsely punctate and rugose except for the glabrous posterior surface. Tibiae almost of the same length, each with an uncus; outer edges costate; inner edges granulated, rugosely scluptured. Fore tibiae slenderer, almost straight 
in the middle, strongly curved at base, slightly curved on apical $1 / 3$, inner edge scarcely bisinuate. Middle tibiae flat, truncate at apex, strongly curved at base, then straight externally to the laminate projection, weakly bisinuate internally, dilated intenally to basal $2 / 5$ and again from apical $1 / 5$ to apex, outer margin costate, with laminate projection posterolaterally at apex, its apex rotundate, its internal surface grooved. Hind tibiae almost straight externally except for strongly curved base and weakly curved apical $1 / 3$, weakly dilated internally from base to apical $1 / 4$.

Venter with 1 st to 4 th ventrites sparsely punctate on the lateral surfaces, conjointly and broadly impressed, 1st ventrite with a long hair tuft along mesial line, which extends laterally to form a pair of hair rows on 2nd and continued to 4 th ventrite along the margins of impression; not costate along margins of elytra. Pygidium separately punctate.

Male genitalia with endophallic sclerites complex and broad, cap-piece emarginate.

Female: Eyes somewhat smaller than those in male, contiguous for a shorter length than in male. Prothorax broader than long. Fore tibiae flattened, inner edge slightly bisinuate. Middle tibiae without the laminate projection. Each tibia uncinate, not mucronate. Abdomen each with double rows of pubescence on basal 3 ventrites and a single row on 4 th ventrite.

Length : 2.8-3.3 mm.

Holotype. $\quad$ (Type No. 2543, Kyushu Univ.), Mt. Daimonji, Kyoto, 19. v. 1979, Y. Sawada leg.

Paratypes. (Hokkaido), Aizankei, Mts. Daisetsu, Hokkaido, 3 우, 1 § , 27-29. vii.1955, K. Morimoto leg. ; Piuka, Teshio, Hokkaido., 1 ð, 12. vii. 1952, T. Shirozu leg.; (Honshu), Yunomata, Oohata, Aomori Pref., 5 우,2 ð, 11. vii-2. viii. 1956, K. Morimoto leg.; Aobajo, Sendai, Miyagi Pref., 2ð, 7. vii. 1956, K. Morimoto leg.; Mt. Myoko, Niigata Pref., 2 ㅇ, 18-19. v. 1976, K. Baba leg. ; Shimashima. dani, Nagano Pref., 1 ㅇ, 28. vi. 1953, S. Ueno leg.; same data as holotype, $1 \sigma^{\star}$.; Sugitoge pass, Omione, Kyoto Pref., 1 우,1 $\sigma^{\star}, 17$. v. 1982, Y. Sawada leg. ; Arashiyama, Kyoto Pref., 5 우,1 1 , 21. vi. 1955, T. Kishii leg*; Mt. Daisen, Tottori Pref., 2 우, 26. v. 1954, S. Kimoto leg. ; (Shikoku), Omogokei, Ehime Pref., 1 우, 3-4. v. 1953, Y. Miyataka leg. ; Mt. Sasa, Hata, Kochi Pref., 1 우, 29. vii. 1953, K. Morimoto leg.; (Kyushu), Mt. Hikosan, Fukuoka Pref., 1 ㅇ, 12. vii. 1955, H. Kamiya leg.; Tano, Bungo-Nakamura, Oita Pref., $1 \precsim$, 19. vii. 1929, Esaki \& Fujino leg.; Mt. Kurodake, Kuju, Oita Pref., 9 우,7ð, 19-21. v. 1984, Y. Sawada leg.

Distribution : Japan (Hokkaido, Honshu, Shikoku, Kyushu)

Note. This species seemingly resembles punctatostriatus. Kôno (1927) identified this species as phaedonius Sharp, and distinguished it from punctatostriatus by the laminal projection of the middle tibiae. Ter-Minassian (1950) also distinguished it by the larger eyes, weaker frontal keel, elongate elytra, etc., and further, Chûjô et Morimoto (1959) distinguished it by less convex abdominal process and hairy male venter. But E. phaedonius is a synonym of punctatostriatus as mentioned above, and new name is given to their phaedonia (nec. Sharp) in this paper. 


\section{Euops clams sp. nov.}

(Figs. 4, 6, 21, 29, 38)

Male. Brazen or metallic green, shiny, elytra sometimes more brilliant than the other parts of body; pronotum, head and sometimes scutellum yellowish green or orange-colored, highly brilliant.

Head weakly elongate, not constricted at base in lateral aspect; dorsum densely punctate, partially wrinkled ; neck region strigulated. Rostrum about 2 times as long as wide at base, straightly and strongly dilated toward apex, maximum breadth $5 / 3$ times as broad as base; sparsely but strongly punctate. Eyes large, contiguous for considerable legnth. Antennae lost in only male specimen examined (in female, 8/7 times as long as pronotum, scape swollen, almost 2 times as long as broad, funicle with 1st segment swollen, as broad as and shorter than scape, 2nd clavate, 3/4 times as long as scape, 2/5 times as broad as long, 3rd almost half as long as 2nd; 4th 3/2 times as long as $3 \mathrm{rd}, 2$ nd to 4 th of the same breadth, 4 th to 7 thsuccessively broader and shorter; 7th dilated apically, broader than long, 1/3 times as long as scape, club with 1st segment a little shorter than scape, almost $3 / 2$ times as long as broad ; 2nd and 3rd each as long as scape, 4/3 times as long as broad; 4th conical, 2/5 times as long as 3rd).

Prothorax a little shorter than broad, broadest at base, constricted near base, then narrowed anteriorly, sides weakly rounded. Dorsum transversely wrinkled and sparsely punctate, pleura above coxae separately punctate.

Scutellum oblong, constricted at middle.

Elytra 1.4 times as long as broad at humeri, slightly tapered posteiorly; striae much narrower than intervals; punctures of stria oblong-oval, indefinitely outlined, with peripheries overlap with adjacent punctures, so that striae slightly hollowed; intervals smooth, with weak transverse strigation and sparse irregular minute punctures ; 1st stria gradually approaching to the sutural ridge from base to middle; 9 th and 10th striae not confluent throughout.

Mesosternum closely and strongly punctate. Mesepisterna and mesepimera finely coriarious, sparsely punctate. Metasternum strongly punctate, punctures arranged in wrinkles at the median area. Metepisterna and metepimera strongly punctate.

Legs stout. Femora clavate, sparsely punctate except for the glabrous posterior surface, apical part coriarious; hind femora a little thicker than the others. Tibiae each with a uncus, coriarious, with setigerous granules; outer edge costate, not milled, inner edge granulate. Fore tibiae a little longer than the others, evenly curved, of the same breadth except for the base. Middle tibiae flat, straight externally except for the base, dilated internally from base to basal 1/3 and again at apex, external margin laminated at apex, with its apex rounded and its posterior surface grooved, costa of middle tibiae milled. Hind tibiae weakly and gradually dilated apically, basal half straight except for the base, apical half curved, outer costa milled. Middle tarsi a little shorter than the others.

Venter with 1 st to 5 th ventrites sparsely punctate and partially strigated; 


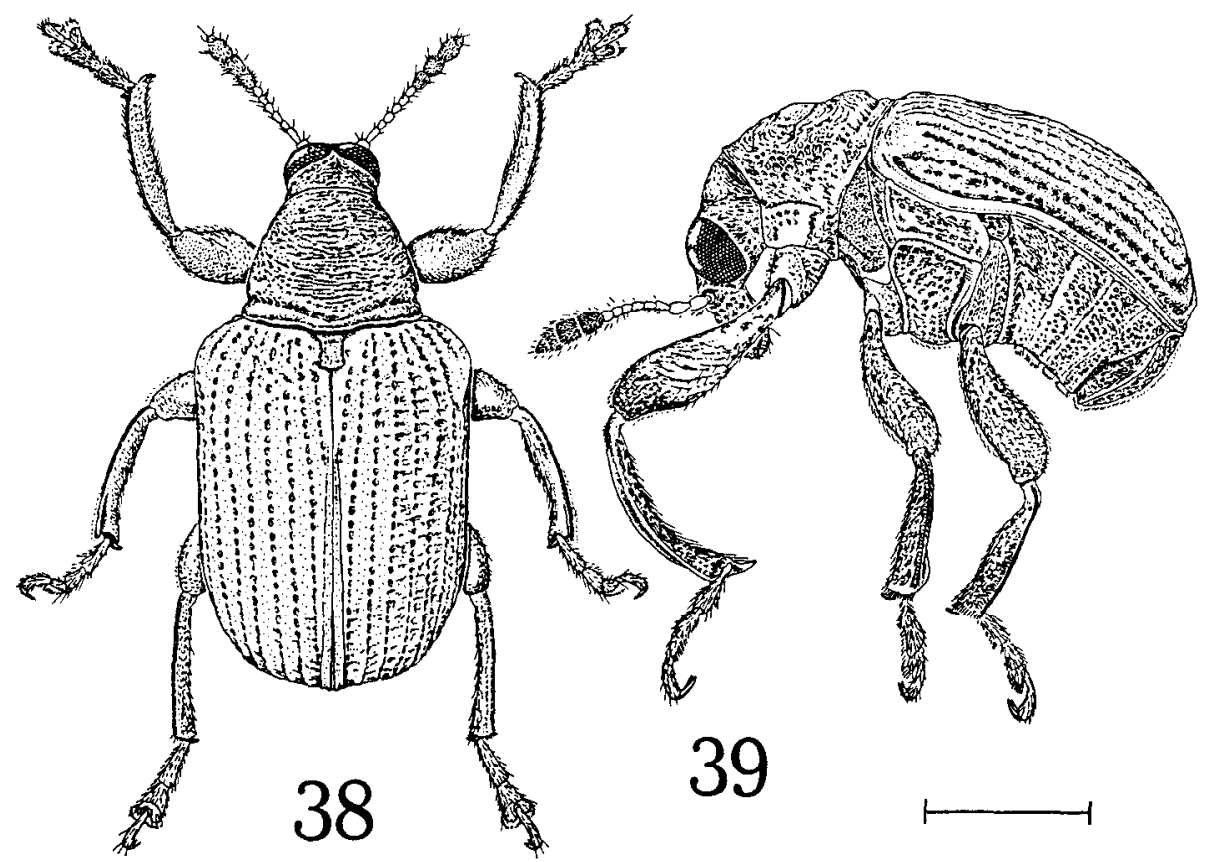

Fig. 38. Euops clarus sp. nov. ð๐. Fig. 39. E. lespedezae koreanus status nov. ð’. Scale : $1 \mathrm{~mm}$.

1st to 4th ventrites conjointly broadly depressed, almost flat; with a narrow mesial glassy impression from basal $1 / 3$ of 1 st to middle of 4 th ventrites, lateral part of 1 st to 4 th ventrites costate along margins of elytra. Pygidium separately punctate, basal part covered by elytra at sides.

Male genitalia with endophallic sclerites small.

Female: Eyes somewhat smaller than those in male, contiguous to each other for a shorter length, fore tibiae as long as hind ones, inner edge slightly bisinuate, middle tibiae not laminate apically, all tibiae uncinate and mucronate; Abdomen each with double rows of pubescence on basal 3 ventrites and a single row on 4 th ventrite.

Length :2. 8-3.3 $\mathrm{mm}$.

Holotype. $\precsim$ (Type No. 2544, Kyushu Univ.), Sungkang, Lenai, Nantou Hs., 15. iv. 1977, Y. Watanabe leg.

Paratypes. Same locality as holotype, 1 우, 1. vi 1965, T. Shirozu leg.; Mt. Lalashan 1300-1500 m., Taoyuan Hs., 3 ㅇ, 17. iv. 1981, H. Takemoto leg.

Distribution : Taiwan.

Note. This species is easily distinguished from the other species of this area by its remarkable sculpture of the pronotum, which is similar to Euops suffundens from Ceylon. Present new species is, however, different from $\boldsymbol{E}$. suffundens in the following characters; 1) the pronotum is more conical, 2) the elytra are less tapered, 3) the pronotum and elytra are not the same in 
coloration.

\section{Euops chinensis Voss}

(Figs. 22, 34, 42)

Euops chinensis Voss, 1922, Deut. Ent. Zeit., 1922: 166, (China, Canton) ; Voss, 1924, Deut. Ent. Zeit., 1924: 43, 55-56, (Formosa); Voss, 1924, Deut. Ent. Zeit., 1924: 279; Voss, 1925, Stett. Ent. Zeit., 85: 297; Kono, 1927, Ins. Mats., II: 39, 41-42; Voss, 1939, Mitt. Münch. Ent. Ges., 29: 615; Voss, 1941, Mitt. Münch. Ent. Ges., 31: 247; Voss, 1958, Decheniana. Beih., 5: 14-15.

Euops chinensis f. purpurea Kono, 1927, Ins. Mats., II: 39, 42.

Metallic green, shiny, head yellowish, elytra blue or purple (f. purpureus), pronotum with a pair of longitudinal purple stripes. Eyes obviously separated. Head constricted. Pronotum vortically punctate, punctures scarcely wrinkled. Elytra slightly tapered posteriorly; 1st stria gradually approaching to suture from base to apex; 9th stria confluent with 10th above the middle of 1st ventrite. Venter costate along the margins of elytra, costae continued to the posterior edge of 6 th tergite of abdomen.

In male, fore tibiae elongate and arched, middle tibiae without laminate projection, 1st to 3rd ventrites conjointly depressed, each with a pubescent and densely punctate median fovea; genitalia with endophallic sclerites long.

Specimens examined: 34 exs from Taipei, Taoyuan, Ilan, Miaoli, Nantou, Hualien, Chiayi, Taitung and Pingtung Hss.

Distribution : China (Kanton, Fukien), Taiwan.

\section{Euops lespedezae lespedezae Sharp}

(Figs. 10, 30)

Euops lespedezae Sharp, 1889, Trans. Ent. Soc. London, 1889: 55-56; Kôno, 1927, Ins. Mats.,

II: 40-41; Yuasa et Kôno, 1950, Icon. Ins. Jap., Ed. sec., 1285; Hirano, 1954, Kontyû, 21: 6-7; Chûjồ et Morimoto, 1959, Kontyû, 27: 146-147; Nakane, 1963, Icon. Ins. Jap. Col. nat. ed. Vol. 2 (Col.): 335, pl. 178; Matoba, 1975, Nankisejbutsu, 17: 19, 20; Morimoto, 1984, Coleopt. Jap. Col., Vol. IV: 259, pl. 51.

Euops splendens Var. b Schilsky, 1903, Käf. Eur., XL: 61.

Euops splendens f. unicolorata Voss, 1924, Deut. Ent. Zeit., 1924: 43, 56; Voss, 1925, Stett. Ent. Zeit., 85: 297; Kôno, 1927, Ins. Mats., II: 39, 41.

Euops splendida f. unicolorata: Yuasa et Kono, 1950, Icon. Ins. Jap., Ed. sec.,: 1285; Iga, 1955, Col. Ill. Ins. Jap. (Col.),: 143, pl. 51.

Black or dark brown with purple or violaceous shimmer. Eyes obviously or slightly separated. Head constricted at base. Elytra almost parallel-sided except humeri, or slightly tapered posteriorly; 9th stria confluent with 10th above the middle of 1 st ventrite. Venter weakly costate along margins of elytra.

In male, fore tibiae elongate and arched; middle tibiae with the laminal projection; the 1 st to 4 th ventrites flattened medianly, median part foveolate and hairly. Genitalia with endophallic sclerites complex, ventral plate of me- 
dian lobe as broad as apex of cap-piece.

Specimens examined: Sapporo, Hokkaido., 1 우, 25. vi. 1958, Y. Takenouchi leg.; 113 exs from Miyagi, Gunma, Yamanashi, Tokyo, Kanagawa, Mie, Kyoto, Nara, Osaka, Hyogo, Hiroshima, Tottori, Tokushima, Ehime, Kochi, Fukuoka, Oita, Miyazaki, Kumamoto and Kagoshima Prefs.

Distribution : Japan (Hokkaido (new record), Honshu, Shikoku, Kyushu).

Note. This species have properly been distinguished from splendidus by Hirano (1959) and Chûjồ et Morimoto (1959) by the male characters of legs and abdomen.

\section{Euops tespedezae koreanus Voss, status nov.}

(Figs. 32, 39)

Euops splendens f. koreana Voss, 1924, Deut. Ent. Zeit., 1924: 43: 43, 56; Voss, 1925, Stett.

Ent. Zeit., 85: 297; Kôno, 1927, Ins. Mats., II: 39, 41.

Euops lespedezae: Ter-Minassian, 1950, Fauna SSSR., 27 (2): 179, 182.

Black or brown with violaceous or green shimmer, elytra with greenish blue lustre. Male genitalia with ventral plate of median lobe much broader than apex of cap-piece.

Specimens examined: Mt. Sudo, Gyongsangbug Do, Korea, 18 우,26 §, 28-30. v. 1979, K. Yamagishi leg., Kwangnung, Pocheon, Gyeonggi Do, 3 우,1 $\delta^{\star}, 16$. v. 1984, K. Morimoto leg., Hongcheon, Gangweon Do, lb, 18-19. v. 1984, K. Morimoto leg.; Tsutsuse, Tsushima, 10 우,10 $\jmath^{\circ}, 22-25$. v. 1985, Y. Sawada leg., Sasu, Tsushima, 2 우,2ð, 21-31. vii. 1959, T. Kishii leg., Sasu, Tsushima, 1 ㅇ, 23. v. 1961, Y. Kimura leg.

Distribution : Japan (Tsushima), Korea, Kirin, Primorskii.

Note. Specimens collected from Korea and Tsushima are different from Japanese ones in shape of aedeagus. These are considered to be geographically isolated populations of a species. Voss (1941) described E. lespedezae f. cuprinipennis based on two Manchurian specimens, the body of which is blue and the elytra are brilliant coppery, according to the description. We can not conclude its position in relation to subspecies koreanus, whether it is a colour variant or another subspecies, due to the lack of available specimen.

\section{Euops splendidus Voss}

(Figs. 8, 9, 13, 33)

Attelabus (Euscelus?) splendens Roelofs, 1874, (nec Gyllenhall, 1839), Ann. Soc. Ent. Belg., 17: 139.

Euops splendens: Sharp, 1889, Trans. Ent. Soc. London, 1889: 55; Schilsky, 1903, Käf. Eur.,

XL: 61; Voss, 1924, Deut. Ent. Zeit., 1924: 43, 56; Stett. Ent. Zeit., 85; 297; Kôno, 1927, Ins. Mats., II: 39, 41; Yokoyama, 1931, Zoku Nihon no Kotyû, 60, pl. 8.

Euops splendens f. nigra Kôno, 1927, Ins. Mats., II: 39, 41.

Euops splendida Voss, 1930, Col. Cat., 110: 35, (new name for splendens Roelofs) ; Yuasa, 1932, Icon. Ins. Jap.,: 532; Kato, 1933, Three Col. Ill. Ins. Jap., Fasc. IX: pl. 22; Ter- 
Minassian, 1950, Fauna SSSR., 27 (2) : 179-181; Yuasa et Kôno, 1950, Icon. Ins. Jap., Ed. sec.,: 1285; Hirano, 1954, Kontyb, 21: 7; Iga, 1955, Coll. Ill. Ins. Jap. (Col.),: 143, pl. 151; Chûjô et Morimoto, 1959, Kontyb, 27: 146-147; Nakane, 1963, Icon. Ins. Jap. Col. nat. ed., Vol. 2 (Col.): 335, pl. 178; Suda, 1965, in Furukawa et al., Genshoku Kontyû Hyakka-zukan,: 232, 568; Matoba, 1975, Nankiseibutsu, 17: 19; Morimoto, 1984, Coleopt. Jap. Col., Vol. IV: 259, pl. 51.

Euops splendida f. nigra: Yuasa et Kôno, 1950, Icon. Ins. Jap., Ed. sec.,: 1285; Iga, 1955,

Coll. Ill. Ins. Jap. (Col.),: 143.

Brazen elytra greenish blue or blue, pronotum yellow or yellowish green with a pair of dark spots. Eyes obviously separated. Head constricted at base. Elytra almost parallel-sided except humeri, or tapered posteriorly; 9th stria confluent with 10th above the middle of 1st ventrite. Venter weakly costate along margins of elytra.

In male, front tibiae elongate and arched; laminal projection of middle tibiae slightly developed; 1 st to 4 th ventrites weakly depressed, not flat, each with a minute pubescent fovea; genitalia with endophallic sclerites complex and ringed, cap-piece constricted.

Specimens examined: 367 exs from Honshu, Shikoku, Kyushu.

Distribution : Japan (Honshu, Shikoku, Kyushu).

\section{Euops striatus Voss}

(Figs. 23, 35, 43)

Euops striata Voss, 1924, Deut. Ent. Zeit., 1924: 279; Voss, 1925, Stett. Ent. Zeit., 85: 297, 1925; Kôno, 1927, Ins. Mats., II: 39, 40.

Male. Reddish black, with weak metallic shine, scutellum coppery, antennae brown. Eyes contiguous for a moderate length. Elytra tapered posteriorly ; 1st stria approaching to suture from base to basal third; 9th stria confluent with 10th above 1st ventrite. Laminate projection of middle tibia weakly developed. Venter weakly depressed on only two anterior ventrites, depressed area of the 1 st ventrite triangular, with pubescence; 1 st to 4 th ventrites costate along margins of elytra. Genitalia with median lobe stout, endophallic sclerites complex and large.

Female unknown.

Specimens examined: Lushanwenchuan 1000 m, Nantou Hs., $1{ }^{\star}, 26$. iv. 1981, K. Ohara leg.; Jihyuehtan, Nantou Hs., $1 \delta^{\star}, 19$. iii. 1980, H. Tsuji leg.

Distribution : Taiwan.

\section{Subgenus Kobusynaptops Kôno}

Kôno, 1927, Ins. Mats., II: 39, 40.

Type-species: Euops pustulosa Sharp, by original designation. 

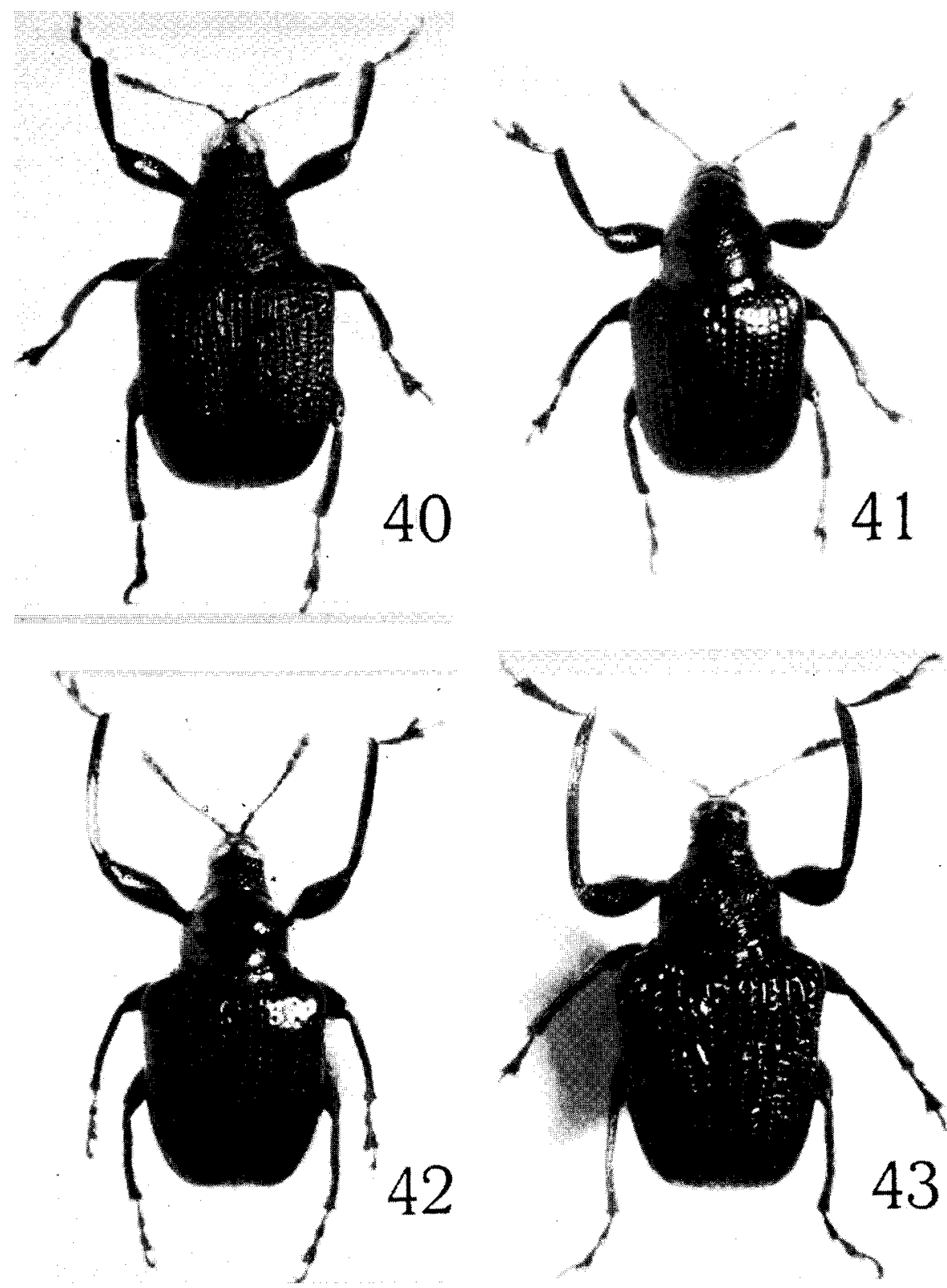

Fig. 40. Euops championi $\partial$; Fig. 41. E. indigenus $\partial$; Fig. 42. E. chinensis $\partial$; Fig. 43. E. striatus $\partial$. 


\section{Euops pustulosus Sharp}

(Figs. 18, 31)

Euops pustulosus Sharp, 1889, Trans. Ent. Soc. London, 1889: 56-57; Schilsky, 1906, Käf. Eur., XLII: 91; Voss, 1924, Deut. Ent. Zeit., 1924: 56.

Euops pustulosa: Voss, 1924, Deut. Ent. Zeit., 1924: 43; Voss, 1925, Stett. Ent. Zeit., 85: 297; Kôno, 1927, Ins. Mats., II: 40; Hirano, 1954, Kontyû, 21: 1-3; Iga, 1955, Col. Ill. Ins. Jap. (Col.) , : 143, pl. 51; Chûjô et Morimoto. 1959, Kontyû, 27: 146-147; Nakane, 1963, Icon. Ins. Jap. Col. nat. ed., Vol. 2 (Col.): 335, pl. 178; Matoba, 1975, Nankiseibutsu, 17: 19; Morimoto, 1984, Coleopt. Jap. Col., Vol. IV: 259, pl. 51.

Derm pustulous. Eyes contact to each other at a point, or shortly contiguous. Head constricted at base. Scutellum impressed, constricted at the middle, or sometimes parallel-sided. Elytra almost paralell-sided except humeri or slightly tapered posteriorly, striae irregularly arranged. Venter costate along the margins of elytra, costae continuing to basal edge of pygidium.

In male, fore tibiae somewhat elongate ; laminate projection of middle tibiae recognized; the 1st to 4 th ventrites flattened medianly; genitalia with endophallic sclerites complex.

Specimens examined: 19 exs from Aomori, Nagano, Kyoto, Hyogo, Tokushima and Fukuoka Prefs.

Distribution : Japan (Honshu, Shikoku, Kyushu, Tsushima).

\section{REFERENCES}

Chûjồ, M. and K. Morimoto 1959 Curculionid-beetles of Niigata Prefecture collected by Dr. K. Bada (2nd report). Kontyû, 27: 146-155

Hamilton, R. W. 1979 Taxonomic use of endophallic structures in some Attelabidae and Rhynchitidae of America, Noth of Mexico (Coleoptera: Curculionoidea), with notes on nomenclature. Ann. Ent. Soc. Amer., 72: 29-34

Hirano, C. 1954 On the Japanese species of the genus Euops (Coleoptera, Curculionidae).

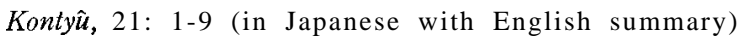

Jeke1, H. 1860 Insecta Saundersiana: Coleoptera. Curculionides. Janson, London

Kôno, H. 1927 Beitrag zur Kenntnis der Attelabinen-fauna Japans. Ins. Mats., 2: 34-61

Lacordaire, M. 1863 Genera des Coléoptères. VI., Paris

Matoba, I. 1975 Notes on the genus Euops Schönherr from Wakayama Prefecture (Coleoptera, Attelabidae). Nankiseibutsu, $17: 19-20$ (in Japanese)

Morimoto, K. 1962 a Comparative morphology and phylogeny of the superfamily Curculionoidea of Japan. J.Fac. Agr., Kyushu Univ., 11: 331-373

Morimoto, K. 1962 b Key to families, subfamilies and genera of the superfamily Curculionoidea of Japan excluding Scolytidae, Platypodiae and Cossoninae. J.Fac. Agr., Kyushu Univ., 12: 21-66

Morimoto K., M. Hayashi and S. Kimoto 1984 The Coleoptera of Japan in color, IV. Hoikusha, Osaka (in Japanese)

Motschulsky, V. 1860 Insectes du Japon. Etud. Ent., 9: 4-39

Schilsky, J. 1903, 1906. In “Käfer Europa's,” ed. by H. C. Küster und G. G. Kraatz, Nürnberg, XL: 1-100, A-PP ;XLII : 1-100

Sharp, D. 1889 II. The rhynchophorous Coleoptera of Japan. Trans. Ent. Soc. London 
$1889: 41-75$

Shirôzu, T. and A. Miyata, 1967 A list of insects from Tsushima. In "Life of Tsushima," ed. by Biol. Soc. Nagasaki Pref., Nagasaki, pp. 567-814 (in Japanese)

Ter-Minassian, M. E. 1950 Fauna SSSR. 27 (2) Attelabidae. Nauk, Leningrad (in Russian) Voss, E. 1922 a Neue Rüsselkäfer aus verschiedenen Erdteilen. Deut. Ent. Zeit., 1922: 166174

Voss, E. 1922 b Kurze Bemerkungen über Rüsselkäfer. Deut. Ent. Zeit., 1922: 174

Voss, E. 1924a Die Gattung Euops Schh. (Col.Curc.).Deut. Ent. Zeit., 1924: 33-65

Voss, E. 1924 b H. Sauters Formosa-Ausbeute. Curculionidae : Attelabinae. (Col.). Deut. Ent. Zeit., 1924: 278-284

Voss, E. 192551929 Die Unterfamilien Attelabinae und Apoderinae. (Col. Curc.). Stett. Ent., Zeit. 85: 191-304,2pls

Voss, E. 1930 Coleopterorum Catalogus. (110) Curculionidae : Attelabinae. Junk, Berlin

Voss, E. 1939 Über einige ostasiatische Rhynchitinen, Attelabinen und Apoderinen. Mitt. Münch. Ent. Ges., 29: 608-616

Voss, E. 1941 Bemerkenswerte Riisselklfer aus Mandschukuo (Coleoptera :Curculionidae.). Arb. Morphol.Taxon. Ent. Dahlem, 8: 109-118

Voss, E. 1942 U̇ber einige in Fukien gesammelte Rüßler. II. Mitt. Münch. Ent. Ges., 32 : 89-105

Voss, E. 1953 Coleopterorum Catalogus Supplementa. Attelabinae. Junk, 's-Gravenhage

Voss, E. 1958 Ein Beitrag zur Kenntnis der Curculioniden im Grenzgebiet der Orientalischen zur Paläarktischen Region (Col., Curc.). Decheniana Beih., 5: 1-139, 1 tab. 